\title{
ONLINE CONSUMER ANALYSIS OF INDONESIAN TRADITIONAL BATIK PRODUCTS
}

\author{
Hatane Semuel \\ Faculty of Business and Economics, Petra Christian University \\ Jl. Siwalankerto 121-131, Surabaya 60236, Indonesia \\ Email: samy@petra.ac.id
}

\begin{abstract}
This study aims to understand website user behavior and online shopping behavior intentions through website facilities and to address the problems of Indonesian traditional batik SMEs in carrying out online marketing. Web services are seen from the security, navigation capabilities, and visual appeal of the website. The study was conducted on 150 students and 96 SME batik owners who have positioned themselves as potential consumers. The respondents were asked to visit the Legendabatik.com website and then answer the questionnaire in the google form. The results found that all website facilities have a positive effect on intention to use, only visual appeal has a direct positive effect on online behavioral intentions, while intention to use has a strong positive influence on online behavioral intentions. So website management needs to prioritize the visual appeal to increase online shopping behavior intention.
\end{abstract}

Keywords: Legendabatik.com website; security; navigation; visual appeal; online behavior.

\section{Introduction}

Indonesia is a country of various islands, tribes and cultures, it reflects on its traditional decorative arts. One of the traditional decorative arts products is known as Indonesian traditional batik. Batik crafts in Indonesia have been known since the age of the Majapahit kingdom, and developed into the property of Indonesian people. The batik industry constitutes of one of 14 classified creative industries in Indonesia featuring world famous specific Indonesian. As a part of creative industry, batik design and the batik product are possible continuously develop. The various culture of Indonesia is an anvil of economic creative development has been developed by the Government of Indonesia to increase export value (Steelyana, 2012).

The introduction of Indonesian batik handicraft products in the world has increased its use, so that a campaign through media is needed to reach wider consumers. Communication carried out by individuals and organizations aims to have a positive impact on product introduction with a desire to make a purchase, (Semuel, Wijaya, \& Tendean, 2017). Online marketing media is considered to be able to fulfill these needs effectively and efficiently. The development of digital media has made it possible to communicate through websites, website applications, cellular applications, animations, short messages, audio visual media, and virtual reality (Lister, Dovey, Giddings, Grant, \& Kelly 2009). Communication using digital media is known as online communication, making the flow of information cannot be limited by time and space
(Campbell \& Park, 2008). The existence of online communication allows something to be very famous or become viral (Bjornson, Van der Perre, Buzzi, \& Larsson, 2019). Viral marketing is a marketing process that aims to promote or convey a message about products and services by encouraging recipients to send and forward it to others (Thompson, 2018).

The effectiveness of a communication is important, and an indicator that is often used as a reference in identifying the output of digital communication is the act of pressing the icon on the interface (Semuel et al., 2017). Digital communication in response to news content in online media is known as a call to action or CTA. In the CTA process, website users need to provide important privacy information (Park \& Gretzel, 2007). CTA is influenced by an individual's interest to provide personal information (Badgaiyana \& Verma, 2015; Verhagen \& van Dolen, 2011; Zhang, Prybutok, \& Strutton, 2007), one's interest can also be influenced (Fill, 2002). In marketing, intentions are related to consumer behavior when he makes purchases (Badgaiyana \& Verma, 2015). Purchase interest can be influenced by the user's background, cultural experience, and the quality of the website which includes the elements and attributes found (Hsu, Chang, \& Chuang, 2015). Millennial generation netizens are new target markets that have different buying behavior characteristics from the existing consumer groups. According to the 2019 Indonesia Millennial Report, millennials often look for price comparisons, features, promo programs and product quality in several e-commerce sites before deciding to buy an item. Millennials also do not hesitate to recommend e-commerce or favorite online 
stores to their friends (Rahayu \& Kumairoh, 2019). This research is conducted to understand the behavior of millennial internet users as a potential market for Indonesian traditional batik products, in addition it would be very good if SME producers could understand their markets.

Although there is a lot of research on the quality of the website in relation to online purchase intentions, but related to a website that displays traditional lagenda content on batik designs has never been done accompanied by the facilities of its legend, it has not been done much nor evaluated, this is the novelty of this research.

\section{Web Quality and Online Behavior Intention}

Based on a survey which is conducted by the Indonesian Ministry of Communications and Information Technology, it is estimated that the level of internet users in Indonesia in 2018 has reached 123 million users, and it put Indonesia in the $6^{\text {th }}$ rank in the world after China, US, India, Brazil and Japan (Hidayat, 2014). The survey results of the Indonesian Internet Service Providers Association (APJII) in 2019, found 117.17 million people out of 264.16 million internet users in 2018 in Indonesia. This has an impact on increasing e-commerce business in Indonesia. The Indonesian Central Statistics Agency states that the ecommerce industry in the last 10 years has increased by 17 percent, and the total number of e-commerce businesses has reached 26.2 million units, and the huge potential of the e-commerce industry in Indonesia is influenced by millennial generation online shopping style (Rahayu \& Kumairoh, 2019). This makes the website's role becomes essential for the business marketing. In its development, many companies that utilize the existence of websites are limited to digital brochures that provide general information about the company, without using it further as a tool that can facilitate business processes. The internet provides a means for the development of a sustainable infrastructure for sending information and business transactions (Cai, Card, $\&$ Cole, 2004).

Security of a website is an important main factor of a website that is highly considered by consumers. The high level of security of a website will affect consumer buying behavior (Wells, Parboteeah, \& Valacich, 2011). A website is considered safe if the user feels safe when making transactions, administrators do not misuse consumers' personal data, and the security and privacy policies are clearly displayed (Akram et al., 2018).

Visual appeal of the website has the significant effect towards the customer purchase behaviour (Wells et al., 2011). A website with the good layout and appearance tends to lead the customer to do the impulsive purchase (Wells et al., 2011). The visual appeal of a website includes the colours, layouts, texts which satisfy the customer's eye (Loiacono, Watson, \& Goodhue, 2002). A website is considered to have a visual appeal if its display, layout, and the design are catchy and interesting (Loiacono et al., 2002).

Navigabilty is very closely related to the ease of using websites. Some researchers such as (Akram et al., 2018; Turkyilmaz, Erdem, \& Uslu, 2015; Wells et al., 2011) state that navigabilty or ease to use has a positive and significant effect on consumer buying behavior. Navigabilty has a positive relationship with intention to use (Semuel, Wijaya, \& Devie, 2019). Indicators for measuring navigabilty include: the attracttive display and easy-to-see website pages, texts on websites is easy to read, website usage is not difficult for new users, and the ease to master the website operational (Akram et al., 2018; Wells et al., 2011).

Most of one's actions can be realized due to interest, although someone can take certain actions with or without reason (Keown \& George, 2013). Interest in doing something can lead someone to take further action, although in some cases it is found that not all intentional actions will lead to further actions (Wathen \& Burkell, 2002). Interest consists of perspective and interest in acting (Searle, 1993). Perspective interest is intended when someone is interested in taking action $\mathrm{A}$ in the future, while for the interest in acting means to take action A now. Interest can be formed when individuals or potential customers receive a lot of information about a product, then the information can increase the desire to act (Lagrosen, 2005). Interest is the tendency in an individual to be attracted to an object or like an object. In addition, interest is the driving force that causes someone to pay attention to certain people, things, and activities. Interest is a strong desire to achieve what someone wants and will not allow anything that can interfere with the achievement of these goals (Dyer, 2010). Simply stated, interest is a tendency and excitement that is high or a great desire for something (Muhibbin, 2011).

Intention to use can be defined as a form of user desire to use or reuse a particular object. In addition, intention to use is also defined as an individual's commitment to a particular technology and a tendency to perform certain specific behaviors. Intention to use can also be interpreted as a tendency to use a product or service and in general based on the suitability between the motives of use with the attributes or characteristics of the product by certain users to achieve goals effecttively, efficiently and satisfaction (Lagrosen, 2005).

The usefulness of a website is the extent to which the website can facilitate the user to reach the goals set 
for a particular context (Badgaiyana \& Verma, 2015). If it is viewed from an effective perspective, it can be defined as the accuracy and completeness used by website users to achieve purchase goals, and the collection of information when visiting a website (Lagrosen, 2005). This is directly related to the right function so users can do it or want to do it when he is visiting websites. Like the efficient consideration factor, which refers to the resources expended to achieve the goal, the user feels efficient when reaching the goal quickly and only requires a little sacrifice. For example, consumer feels more efficient on a user-centered website with simple and consistent features across all pages. This makes the web page easy to read and learn, so it can have an impact on satisfaction. Satisfaction here is defined as the comfort and acceptance of users of a website. When a website provides various options to support users and privacy services that are reliable and safe, it will have an impact in increasing the satisfaction of website users.

The integrated and creative design of the website quality is needed to improve the performance of online communication. There are two main approaches in evaluating website quality, from the perspective of consumer usability and business perspective (Gregory Wang, \& DiPietro, 2010). From the perspective of consumer usability, the main focus considered to create quality websites includes: practicality and useful content; the ability of the website to navigate; website's ability to facilitate the business transactions desired by consumers, communication, purchasing, and website's ability to entertain (Gregory et al., 2010). The quality of the website from a consumer's perspective include: the quality of information, the ease of use of the website, the level of response, the level of security or privacy; trust; interactivity; and personalization (Park \& Gretzel, 2007). There are three dimensions of website quality that have an important role for consumers, there are security, navigabilty, and visual appeal (Wells et al., 2011). There is a dimension of website quality that is considered by consumers to include security, visual appeal, and navigability (Wells et al., 2011). Security of a website is an important main factor of a website that is highly considered by consumers, and the high level of security of a website will affect consumer buying behavior (Wells et al., 2011). The hypothesis from the description is:

$H_{l}$ : Security has a positive effect on online behavior intention

A good website quality will have a positive impact on consumer purchasing decisions (Akram et al., 2018; Turkyilmaz et al., 2015; Wells et al., 2011). Therefore, web quality is an important factor that can influence the success of an online store (Wells et al.,
2011). According to (Cunliffe, 2000), poor web design will result in a loss of 50 percent of potential sales because users cannot find what they want, and will lose 40 percent of the potential for revisits due to negative initial experiences.

$\mathrm{H}_{2}$ : Visual appeal has a positive effect on online behavior intention

Navigabilty of a website includes ease of use of the website (Wells et al., 2011). There was a positive impact between website quality on customer satisfaction and interest in buying behaviour (Bai, Law, \& Wen, 2008). In addition, there is a direct influence on the quality of the website on behavioral interest (Olorunniwo, Hsu, \& Udo, 2006). Websites navigation influence users' fluency of visiting website experiences (Novak, Hoffman, \& Yung, 2000) and their attitudes towards the website. Richard (2005) suggested that navigational cues of websites were related to consumers' behavior of visiting and purchasing. The hypothesis from the description is:

$H_{3}$ : Navigabilty has a positive effect on online behavior intention

\section{Web Quality and Intention to Use}

A website is said to be safe if the user feels safe when making transactions, administrators do not misuse consumers' personal data, and the security and privacy policies are clearly displayed (Akram et al., 2018). The planned behavior theory is the actual direct antecedent of a behaviour, while interest in behavior is the subjective possibility of individuals who perform certain behaviors, and is a major determinant of actual use behavior (Ajen, 1985; Fishbein, Jaccard, Davidson, Ajzen, \& Loken, 1980; Yi, Jackson, Park, \& Probst, 2006). Based on the previous research, it is easy to collect data about behavioral interest in actual behavior that has contributed broadly to their application in the context of hotel and tourism research (Buttle \& Bok, 1996). Previous research that tried to test the adoption of electronic distribution channel users mainly focused on two directions: (1) online information search as a stage in the consumer decision making process, and (2) interest in buying choices distribution channels and online (Kim \& Fesenmaier, 2008). But the results show that it does not fully understand the psychological process of choosing distribution and ordering channels (Semuel et al., 2017).

Website visitors can be divided into two types based on search objectives. First, customers who are looking for information to facilitate purchasing decisions and second is customers who are looking for 
information and are free from buying certainty (Loiacono et al., 2002). Using websites to search for information and make purchases are two different behaviors (Loiacono et al., 2002). Critics of measuring behavior of interest in previous e-retail studies, show that these variables must be clearly defined and analyzed separately because interest in repurchasing, interest in WOM, and interest in review represent different behaviors (Bergkvist \& Rossiter, 2007). Website quality is an important factor that influences the success of an online store (Wells et al., 2011). The visual appeal of a website such as color, sound, layout, and even graphic design will create a website atmosphere that drives the Stimulus-OrganismResponse (S-O-R) of customers (Semuel et al., 2017). Then this positive impact will make customers want to do a search on the website with a longer duration. Not only that, security is also one dimension of web quality that can increase people's attention to want to access the website. Based on the description above, the hypothesis can be built as follows:

$H_{4}$ : Security has a positive effect on intention to use

$H_{5}$ : Visual appeal has a positive effect on intention to use

$H_{6}$ : Navigabilty has a positive effect on Intention to Use

\section{Intention to Use and Online Behavior Intention}

Based on a study conducted by Semuel et al., (2017) it is found that interest in using websites among young people had a strong positive influence on behavioral interests related to interests in buying traditional Indonesian decorative products online. In addition, the interest to use a website is a perfect mediation between the quality of the website against behavioral interest (Semuel et al., 2017; Akram et al., 2018). When consumers have the intention/good attention to a website, it will make them want to try shopping through the web. Based on the description above, the hypothesis can be built as follows:

$H 7$ : Intention to use has a positive effect on behavioral intention.

\section{Research Methods}

The population of this research are all batik consumers who like traditional Indonesian batik products. The number of samples 246 has met for the SEM model, if referring to the opinion of Hair Jr., Black, Babin, and Anderson (2014), with a minimum size of 5-10 times the estimated number of parameters. In this study there are 32 parameters to be estimated, so that the minimum sample size is $160-320$ respondents. The sample is filling out the online questionnaire on google form link: https://docs.google. com/forms view form. Netizens participated in this research are 150 students who were participants of the 2019 odd semester Mathematics course at the Petra Christian University Business and Economics Faculty, and 96 SME batik business people who positioned themselves as consumers from July 2019 to October 2019, were asked to look at the Legendabatik.com website, then answer the online questionnaire on the google form. In addition, FGDs were also conducted on each of the 15 traditional batik SMEs in three regions of the provinces of South Sumatra, West Sumatra, and South Sulawesi. Exogenous variable measurement, namely security consists of four indicators, navigation six indicators, visual display four indicators (Wells et al., 2011). Measurement of intention to use mediation variables consists of five indicators, and online behavioral intention as many as six indicators (Semuel et al., 2017). Indicator measurements using a Likert scale with a score of $1=$ strongly disagree until a score of $5=$ strongly agree. The analysis method uses the SEM model and analyzed using the PLS SMART program.

\section{Result and Discussion}

\section{Respondents Profile}

The research data is obtained through filling out an online questionnaire available on Google form with the number of respondents involved in this study is 246 people including 150 Petra Christian University University students, and 96 batik SME business owners who were asked to answer online questionnaires if they had a position as a batik consumer emblazoned on the legendabatik.com website. The origin of students and SME owners is spread across several regions in Indonesia. The data show that $36.2 \%$ are male and $63.8 \%$ are female. Based on the frequency of using the internet in a day there are $39 \%$ very often (> six hours a day), while $47.6 \%$ (two hours-four hours a day), rarely $13.4 \%$ (one hour-two hours a day). If it is classified based on students, it can be seen that respondents do frequent internet activities in a day, there are $54.7 \%$ very often, $42.7 \%$ are moderate and $2.7 \%$ are rare, while the group of SME owners is seen as much as $14.6 \%$ very often, 55.2 moderate $\%$ and $30.2 \%$ are rare. From the purpose of activities using batik clothing in total it appears that $64.2 \%$ for party activities, $35.8 \%$ for other formal activities. When viewed from among students $65.3 \%$ for party activities, $34.7 \%$ for other formal activities, while when viewed from SME owners $62.5 \%$ for party activities, $37.5 \%$ for other formal activities. 


\section{Website Security Indicators}

The research data is obtained through filling out an online questionnaire available on google form with the number of respondents involved in this study as many as 246 people consist of 150 students of Petra Christian University Surabaya and 96 business owners The following is a description of the mean, standard deviation and loading factors of the indicators measurement of website security variables. As in Table 1, it appears that:

Table 1

Mean, SD, Factor Loading, and Crombach Alpha Variable Website Security Indicators

\begin{tabular}{|c|c|c|c|c|c|}
\hline Symbol & Indicators & Mean & $\begin{array}{l}\text { Std. } \\
\text { Dev. }\end{array}$ & $\begin{array}{c}\text { Factor } \\
\text { Loading }\end{array}$ & $\begin{array}{l}\text { Cronbach } \\
\text { Alpha }\end{array}$ \\
\hline SEK1 & $\begin{array}{l}\text { I am confident } \\
\text { that the } \\
\text { information } \\
\text { provided during } \\
\text { the transaction on } \\
\text { the website } \\
\text { legendabatik.com } \\
\text { will be secure }\end{array}$ & 4.144 & .947 & 0.897 & \\
\hline SEK2 & $\begin{array}{l}\text { I am confident } \\
\text { that the transaction } \\
\text { process on the } \\
\text { website } \\
\text { legendabatik.com } \\
\text { will be secure }\end{array}$ & 4.019 & .929 & 0.913 & 0.923 \\
\hline SEK3 & $\begin{array}{l}\text { Ibelieve the } \\
\text { retailer in the } \\
\text { website } \\
\text { legendabatik.com } \\
\text { credible }\end{array}$ & 3.961 & 1.030 & 0.886 & \\
\hline SEK4 & $\begin{array}{l}\text { Security and } \\
\text { Privacy policy } \\
\text { displayed website } \\
\text { legendabatik.com } \\
\text { very clear }\end{array}$ & 3.809 & .991 & 0.780 & \\
\hline
\end{tabular}

Indicators related to I am confident that the information provided during the transaction on the website legendabatik.com will be secure gives the highest value ( $M=4.144)$ and tends to be homogeneous ( $\mathrm{SD}=0.947)$. This shows that the website perceived quality must be able to guarantee the confidentiality of information. The results of the FGD also revealed that the owners of MSMEs argued that the products offered by every manufacturer in an online store must be guaranteed not to be easily imitated by competitors. Other than that The security and privacy policy indicator displayed on legendabatik.com website very clear has the lowest rating $(M=3,809)$ and tends to be homogeneous $(\mathrm{SD}=0.991)$. This shows that the design of legendabatik. com cannot guarantee the security and privacy policy of consumers. The results of the FGD also revealed that MSME owners as consumers think that security and privacy policy must be the main concern of website owners, and should be able to be revealed explicitly and clearly.

\section{Website Navigabilty Indicators}

The highest indicator of variable measurement for website navigabilty is owned by Text on the legendabatik.com website easy to read. As in Table 2, it appears that the NAV6 indicator $(M=4.105)$ is the easy to read Text on the legendabic.com website with relatively small variations $(\mathrm{SD}=0.923$ ) compared to the other indicators. This means that the legendabatik. com website can provide information that is easy for users to navigate. From the loading factor all indicators have valid measurement validity $(\mathrm{fl} \geq 0.70)$, while the Cronbach alpha coefficient 0.933 indicates the indicator has a very good measurement consistency.

\section{Website Visual Appeal Indicators}

The mean results, standard deviations, loading factors, and cronbach alphabets of the Visual Appeal website measurement indicators. As in Table 3, it appears that the layout of Batik products on the website legendabatik.com can be distinguished by the production area indicator The layout of Batik products on the website legendabatik.com can be distinguished by the production area $(\mathrm{M}=4.027 ; \mathrm{SD}=0.907)$ means that the variation of the answer is lower than the other indicators. The high mean value indicates that the legendabatik.com site as a marketplace can display specific regional product results. The results of the FGD with MSME owners in the city of Jambi received input that the typical batik products of Jambi can be seen clearly and in accordance with the original product. The magnitude of factor loading of each indicator has met (fl>0.7) indicating high validity and a Chronbach alpha coefficient of 0.891 fulfilling good reliability requirements.

The FGD results also revealed that the owners of MSMEs as consumers think that the text written on the website about the identity of online stores, story stories, and personal safety are important things that must be considered. This has been seen well done on the legendabatik.com website. 
Table 2

Mean, SD, Factor Loading, and Cronbach Alpha Variable Website Navigabilty Indicators

\begin{tabular}{|c|c|c|c|c|c|}
\hline Symbol & Indicators & Mean & $\begin{array}{l}\text { Std. } \\
\text { Dev. }\end{array}$ & $\begin{array}{c}\text { Factor } \\
\text { Loading }\end{array}$ & $\begin{array}{c}\text { Chronbach } \\
\text { Alpha }\end{array}$ \\
\hline NAV1 & $\begin{array}{l}\text { Navigating the } \\
\text { website page } \\
\text { legendabatik.com } \\
\text { Easy }\end{array}$ & 3.949 & .944 & 0.814 & \\
\hline NAV2 & $\begin{array}{l}\text { I found that the } \\
\text { interaction with } \\
\text { the website } \\
\text { legendabatik.com } \\
\text { understandable }\end{array}$ & 4.012 & .942 & 0.858 & \\
\hline NAV3 & $\begin{array}{l}\text { It's easy for me to } \\
\text { be expert in } \\
\text { navigating } \\
\text { website pages } \\
\text { legendabatik.com }\end{array}$ & 4.031 & .968 & 0.789 & 0.933 \\
\hline NAV4 & $\begin{array}{l}\text { Learning to } \\
\text { operate website } \\
\text { legendabatik.com } \\
\text { is easy for me }\end{array}$ & 4.058 & .969 & 0.801 & \\
\hline NAV5 & $\begin{array}{l}\text { Page display in } \\
\text { website website } \\
\text { legendabatik.com } \\
\text { Easy to read }\end{array}$ & 4.043 & .973 & 0.764 & \\
\hline NAV6 & $\begin{array}{l}\text { Text on website } \\
\text { legendabatik.com } \\
\text { easy to read }\end{array}$ & 4.105 & .923 & 0.971 & \\
\hline
\end{tabular}

Table 3

Mean, SD, Factor Loading, and Cronbach Alpha Variable Website Visual Appeal Indicators

\begin{tabular}{|c|c|c|c|c|c|}
\hline Symbol & Indicators & Mean & $\begin{array}{l}\text { Std. } \\
\text { Dev. }\end{array}$ & $\begin{array}{c}\text { Factor } \\
\text { Loading }\end{array}$ & $\begin{array}{c}\text { Cronbach } \\
\text { Alpha }\end{array}$ \\
\hline VIS1 & $\begin{array}{l}\text { This } \\
\text { legendabatik.com } \\
\text { website is fun } \\
\text { from visual } \\
\text { display }\end{array}$ & 4.016 & .918 & 0.791 & \\
\hline VIS2 & $\begin{array}{l}\text { The website } \\
\text { legendabatik.com } \\
\text { features a visually } \\
\text { pleasing design }\end{array}$ & 3.821 & .939 & 0.822 & \\
\hline VIS3 & $\begin{array}{l}\text { Website Layout } \\
\text { legendabatik.com } \\
\text { has interesting } \\
\text { colors }\end{array}$ & 3.856 & .939 & 0.837 & 0.891 \\
\hline VIS4 & $\begin{array}{l}\text { The layout of } \\
\text { Batik products on } \\
\text { the website } \\
\text { legendabatik.com } \\
\text { can be } \\
\text { distinguished by } \\
\text { production area }\end{array}$ & 4.027 & .907 & 0.833 & \\
\hline
\end{tabular}

\section{Website Intention to Use Indicators}

Here is a description of the mean, standard deviation and loading factors of the Intention to Use website variable measurement indicator. As in Table 4, it appears that the indicator I will be looking for sellers at the traditional batik online shop at legendabatik.com to get the best prices $(M=4.117 ; \mathrm{SD}=0.753)$ shows lower variations than other indicators. That the price of the product is the main factor to encourage the nitizen to want to use the website intensity. This choice is rational from the perspective of consumers in general. The results of the FGD showed that the owners of traditional batik SMEs in the cities of Jambi, Padang, and Makassar believed that determining prices according to product quality was one of the main competitive advantages. The magnitude of factor loading of each indicator has met $(\mathrm{fl} \geq 0.7)$ indicating high validity and a Chronbach alpha coefficient of 0.877 fulfilling good reliability requirements.

Table 4

Mean, SD, Factor Loading, and Cronbach Alpha Variable Website Intention to Use Indicators

\begin{tabular}{|c|c|c|c|c|c|}
\hline $\begin{array}{c}\text { Symbo } \\
1\end{array}$ & Indicators & Mean & $\begin{array}{l}\text { Std. } \\
\text { Dev. }\end{array}$ & $\begin{array}{c}\text { Factor } \\
\text { Loading }\end{array}$ & $\begin{array}{l}\text { Chronbach } \\
\text { Alpha }\end{array}$ \\
\hline INT1 & $\begin{array}{l}\text { I will visit the } \\
\text { traditional batik } \\
\text { online shop on } \\
\text { the website } \\
\text { legendabatik.com }\end{array}$ & 3.988 & .916 & 0.843 & \\
\hline INT2 & $\begin{array}{l}\text { I will be looking } \\
\text { for some sellers } \\
\text { in the traditional } \\
\text { batik online store } \\
\text { on the website } \\
\text { legendabatik.com } \\
\text { to get quality } \\
\text { products }\end{array}$ & 4.070 & .868 & 0.770 & \\
\hline INT3 & $\begin{array}{l}\text { I will be looking } \\
\text { for sellers at the } \\
\text { traditional batik } \\
\text { online shop at } \\
\text { legendabatik.com } \\
\text { to get the best } \\
\text { prices }\end{array}$ & 4.117 & .881 & 0.753 & 0.877 \\
\hline INT4 & $\begin{array}{l}\text { I will visit } \\
\text { legendabatik.com } \\
\text { to get information } \\
\text { about Indonesian } \\
\text { traditional batik } \\
\text { products }\end{array}$ & 3.860 & .974 & 0.785 & \\
\hline INT5 & $\begin{array}{l}\text { I would recom- } \\
\text { mend the website } \\
\text { legendabatik.com } \\
\text { to other friends to } \\
\text { buy traditional } \\
\text { Indonesian batik } \\
\text { products }\end{array}$ & 3.697 & 1.112 & 0.725 & \\
\hline
\end{tabular}


Table 5

Mean, SD, Factor Loading, and Cronbach Alpha Variable Online Behavioral Intention to Use Indicators

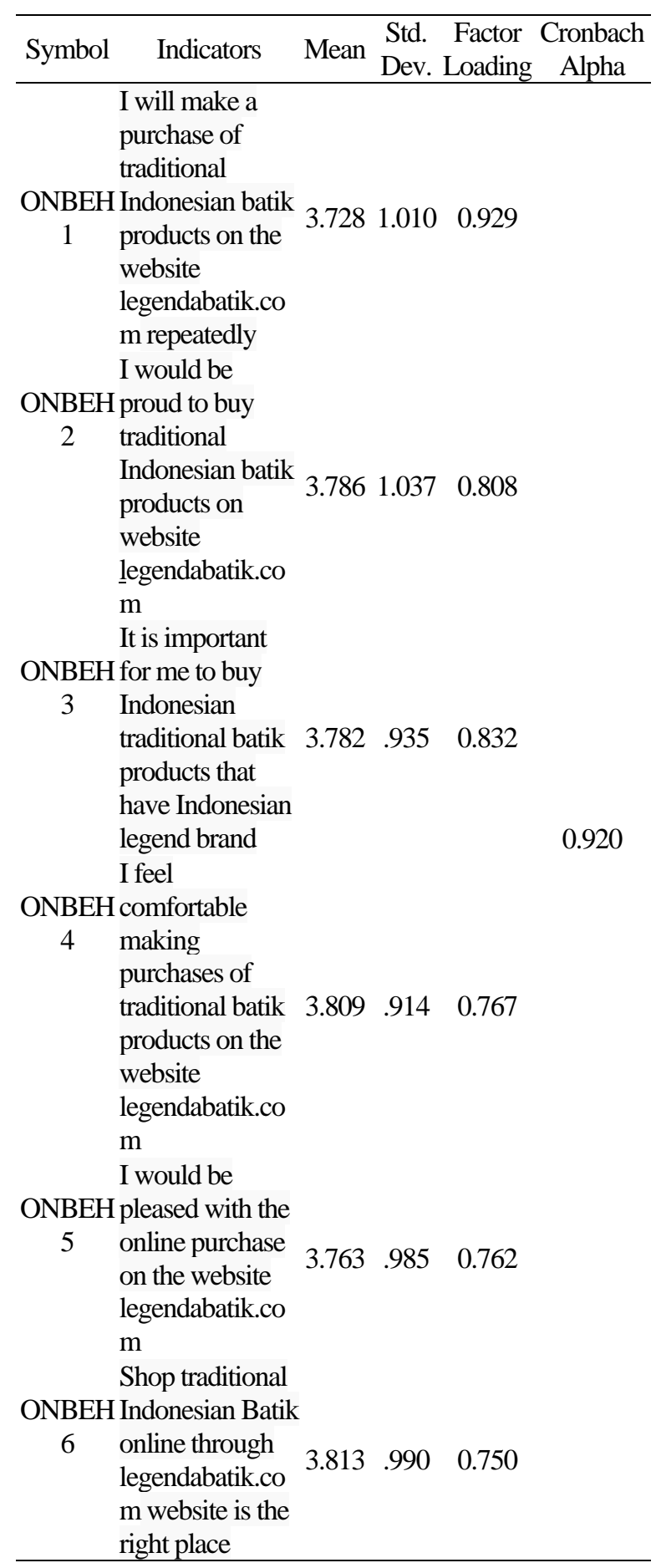

\section{Online Behavioral Intention}

Descriptions of the mean, standard deviation, loading factor and Cronbach alpha of the measurement indicators of the Online Behavioral Intention variable. As in Table 5, it appears that the traditional Indonesian Batik Shop indicator online through legendabatik.com website is the right place $(\mathrm{M}=3,813 ; \mathrm{SD}=0.990)$ has a relatively low variation. The mean value is relatively small, indicating that the website legendabatik.com is considered by customers to be unable to be perceived as the best place to shop for traditional Indonesian batik products. This can happen because the products displayed are not many, so consumer choices are very limited. The loading factor coefficient $\geq 0.70$ and the Cronbach alpha coefficient of 0.920 indicates that the indicators used in measuring online behavioral intention variables are in accordance with the rules of measuring latent variables.

\section{Influence Analysis and Hypothesis Testing}

The results of data processing using the PLS professional program show that all measurement indicators have met the good measurement reliability and validity. The representation of the indicator has been explained in the variable description above. As seen in Table 6. that next to be able to answer the hypothesis testing put forward in this study, visual appeal has a strong influence on online behavioral intention and intention to use the website. This model can also show that the intention to use website can mediate the influence of the three variables of website security, website naviagaility, and website visual appeal to online behavioral intention.

Intention to Use $=0.151$ Security +0.145 Navigation +0.638 Visual Appeal, $\left(R^{2}=0.894\right)$

Online Behavioral Intention $=-0.028$ Security -0.152 Navigation +0.35 Visual Appeal + 0.605 Intention to Use, $\left(R^{2}=0.768\right)$

Based on the $R^{2}$ values of the two equations above, it can be determined the predictive coefficients of this research model are:

$$
\begin{aligned}
Q^{2} & =1-(1-0.894)(1-0.768) \\
& =0.975
\end{aligned}
$$

The coefficient number $Q^{2}$ indicates that the ability to predict online behavioral intention from a security website, a navigabilty website, a website visual appeal, and an intention to use website are $97.5 \%$ of the model. This means that this model can be developed to analyze nitizen online shopping behavior. The results of hypothesis testing can be seen in Table 6. The hypothesis acceptance criteria are based on the pvalue of the regression coefficients of each variable. If the pvalue $<0.05$, then the research hypothesis can be accepted, and vice versa. 
Table 6

Testing the Path Coefficient of the Research Model

\begin{tabular}{|c|c|c|c|c|}
\hline $\begin{array}{l}\text { Relation of } \\
\text { Influence }\end{array}$ & $\begin{array}{l}\text { Original } \\
\text { Sample } \\
\text { (O) }\end{array}$ & $\begin{array}{l}\text { Standard } \\
\text { Deviation } \\
(\mathrm{STDEV})\end{array}$ & $\begin{array}{c}\text { T Statistics } \\
(|\mathrm{O} / \mathrm{STDEV}|)\end{array}$ & $\begin{array}{c}P \\
\text { Values }\end{array}$ \\
\hline$\overline{\text { Inten }}$ & & & & \\
\hline $\begin{array}{l}\rightarrow \text { Online } \\
\text { behavioral }\end{array}$ & 0.605 & 0.082 & 7.389 & 0.000 \\
\hline $\begin{array}{l}\text { Navigabilty } \rightarrow \\
\text { Intention to use }\end{array}$ & 0.145 & 0.078 & 1.860 & 0.032 \\
\hline $\begin{array}{l}\text { Navigabilty } \rightarrow \\
\text { Online } \\
\text { behavioral }\end{array}$ & -0.152 & 0.110 & 1.379 & 0.085 \\
\hline $\begin{array}{l}\text { Security } \rightarrow \\
\text { Intention to use }\end{array}$ & 0.151 & 0.065 & 2.337 & 0.010 \\
\hline $\begin{array}{l}\text { Security } \rightarrow \\
\text { Online } \\
\text { behavioural }\end{array}$ & -0.028 & 0.100 & 0.277 & 0.391 \\
\hline $\begin{array}{l}\text { Visual } \rightarrow \\
\text { Intention to use }\end{array}$ & 0.638 & 0.055 & 11.568 & 0.000 \\
\hline $\begin{array}{l}\text { Visual } \rightarrow \text { Online } \\
\text { behavioural }\end{array}$ & 0.356 & 0.087 & 4.066 & 0.000 \\
\hline
\end{tabular}

With the above criteria it can be concluded that the results of testing the hypothesis of this study are:

$H_{l}$ : Security has a positive effect on online behavior intention is rejected.

$H_{2}$ : Visual Apeal has a positive effect on online behavior intention is accepted.

$H_{3}$ : Navigability has a positive effect on online behavior intention is rejected.

$H_{4}$ : Security has a positive effect on intention to use is accepted.

H5: Visual Apeal has a positive effect on intention to use is accepted.

$H_{6}$ : Navigability has a positive effect on intention to use is accepted.

$H_{7}$ : Intention to use has a positive effect on accepted online behavioral intention is accepted.

\section{Conclusions and Recommendations}

Based on the above discussion it can be concluded: Indonesian traditional batik products, able to actualize regional culture in a variety of regional designs and patterns in Indonesia. Online marketing targeting millennial consumers is a potential segment of traditional Indonesian batik products. Visual apeal is a quality web element that has a strong positive influence on consumer behavior intention and intention to visit a website. Consumers who have the high intention to visit websites will tend to have high behavioral intentions.

Recommendations and limitation given from the results of this study are: The need to prioritize website visual appeal in order to increase the intention to use the website and online behavioral intention. This research has limitations related to not including some elements of website quality related to consumer familiarity with the website such as innovation, emotional attractiveness, consistent images, and online completeness as exogenous variables, so further research can be considered in the construction of the model. In addition, the limitation in terms of millennial respondents is that all are Petra Christian University students, so that further research should be expanded, also applies to owners of Indonesian traditional batik SMEs so that more variations.

\section{References}

Ajen, I. (1985). From intentions to actions: A theory of planned behavior. In J. Kuhl, \& J. Beckmann, (Eds.), Action-control: From cognition to behavior (pp. 11-39). Berlin: Springer-Verlag.

Akram, U., Hui, P., Khan, M. K., Tanveer, Y., Mehmood, K., \& Ahmad, W. (2018). How website quality affects online impulse buying: Moderating effects of sales promotion and credit card use. Asia Pacific Journal of Marketing and Logistics, 30(1), 235-256. https://doi.org/10.1108/ APJML-04-2017-0073

APJII. (2019). Penetration infographics \& behavior of Indonesian internet users. Indonesia: Teknopreneur.

Badgaiyana, A. J., \& Verma, A. (2015). Does urge to buy impulsively differ from impulsive buying behaviour? Assessing the impact of situational factors. Journal of Retailing and Consumer Services, 22, 145-147. https://doi.org/10.1016/j.jret conser.2014.10.002

Bai, B., Law, R., \& Wen, I. (2008). The impact of website quality on customer satisfaction and purchase intentions: Evidence from Chinese online visitors. International Journal of Hospitality Management, 27(3), 391-402. https://doi.org/10.1016/ j.ijhm. 2007.10.008

Bergkvist, L., \& Rossiter, J. R. (2007). The predictive validity of multiple-item versus single-item measures of the same constructs. Journal of Marketing Research, 44(2), 175-184. https://doi.org/10. 1509\%2Fjmkr.44.2.175

Bjornson, E., Van der Perre, L., Buzzi, S., \& Larsson, E. G. (2019). Massive MIMO in sub-6 GHz and mmWave: Physical, practical, and use-case differences. IEEE Wireless Communications, 26(2), 100-108. 
Buttle, F., \& Bok, B. (1996). Hotel marketing strategy and the theory of reasoned action. International Journal of Contemporary Hospitality Management, 8(3), 5-10. https://doi.org/10.1108/095961 19610115943

Cai, L., Card, J. A., \& Cole, S. T. (2004). Content delivery performance of world wide website sites of US tour operators focusing on destinations in China. Tourism Management, 25(2), 219-227. https://doi.org/10.1016/S0261-5177(03) 00095-5

Campbell, S. W., \& Park, Y. J. (2008). Social implications of mobile telephony: The rise of personal communication society. Sociology compass, 2(2), 371-387. https://doi.org/10.1 111/j.1751-9020.2007.00080.x

Cunliffe, D. (2000). Developing usable Website sitesA review and model. Internet Research Networking Applications and Policy, 10(4), 295-307.

Dyer, K. M., \& Renn, M. T. (2010). Getting an education: Schools leaders need specialized development. Leadership in Action, 29(6), 3-7. https://doi.org/10.1002/lia.1311

Fill, C. (2002). Marketing communications, strategies and applications. Third Edition. Harlow: Pearson Education Ltd.

Fishbein, M., Jaccard, J., Davidson, A. R., Ajzen, I., \& Loken, B. (1980). Predicting and understanding family planning behaviors. In I. Ajzen, \& M. Fishbein (Eds.), Understanding attitudes and predicting social behavior. Englewood Cliffs, NJ: Prentice Hall.

Gregory, A., Wang, Y. (R.), \& DiPietro, R. B. (2010). Towards a functional model of website evaluation: A case study of casual dining restaurants. Worldwide Hospitality and Tourism Themes, 2(1), 68-85. https://doi.org/10.1108/175542 11011012603

Hair Jr., J. F., Black, W. C., Babin, B. J., \& Anderson, R. E. (2014). Multivariate data analysis. Seventh Edition. Essex, England: Pearson.

Hidayat, W. (2014). Pengguna internet Indonesia nomor enam dunia. kompas.com. Retrieved from https://kominfo.go.id/content/detail/4286/pen gguna-internet-indonesia-nomor-enam-dunia/0/ sorotan_media

Hsu, M. H., Chang, C. M., \& Chuang, L. W. (2015). Understanding the determinants of online repeat purchase intention and moderating role of habit: The case of online group-buying in Taiwan. International Journal of Information Management, 35 (1), 45-56. https://doi.org/10.1016/j.ijin fomgt.2014.09.002

Keown, J., \& George, R. P. (2013). Reason, morality, and law: The philosophy of John
Finnis. Oxford, UK: Oxford University Press.

Kim, H., \& Fesenmaier, D. R. (2008). Persuasive design of destination website sites: An analysis of first impression. Journal of Travel Research, 47(1), 3-13. https://doi.org/10.1177\%2F004728 7507312405

Lagrosen, S. (2005). Effects of the internet on the marketing communication of service companies. Journal of Services Marketing, 19(2), 63-69. https://doi.org/10.1108/08876040510591376

Lister, M., Dovey, J., Giddings, S., Grant, I., \& Kelly, K. (2009). New media: A critical introduction. Oxon: Routledge.

Loiacono, E. T., Watson, R. T., \& Goodhue, D. L. (2002). WebQual TM: A measure of website quality. Marketing Theory and Applications, 13(3), 432-438. https://doi.org/10.1590/ S0104530X2005000200011

Muhibbin, S. (2011). Psikologi pendidikan. Bandung: Remaja Rosdakarya.

Novak, T., Hoffman, D., \& Yung, Y. (2000). Measuring the customer experience in online environments: A structural modeling approach. Marketing Science, 19(1), 22-42.

Olorunniwo, F. O., Hsu, M. K., \& Udo, G. (2006). Service quality, customer satisfaction, and behavioral intentions in the service factory. Journal of Services Marketing, 20(1), 59-72. https://doi. org/10.1108/08876040610646581

Park, Y. A., \& Gretzel, U. (2007). Success factors for destination marketing website Sites: A qualitative meta-analysis. Journal of Travel Research, 46(1), 46-63. https://doi.org/10.1177/0047287507302 381

Rahayu, N., \& Kumairoh. (2019). Pertumbuhan ecommerce pesat di Indonesia. Wartaekonomi.co. $i d$. Retrieved from https://www.wartaekonomi. co.id/read216302/pertumbuhan-e-commerce-pe sat-di-indonesia.html

Richard, M. O. (2005). Modeling the impact of internet atmospherics on surfer behavior. Journal of Business Research, 58(12), 16321642. https://doi.org/10.1016/j.jbusres.2004. 07.009

Searle, J. (1993). Intentionality: An essay in the philosophy of mind. Cambridge: Cambridge University Press.

Semuel, H., Wijaya, S., \& Devie (2019). The analysis website quality, intention to use the website and behavioral intention nitizen Indonesia batik-tenun traditional products of Indonesia. International Journal of Recent Technology and Engineering (IJRTE), 8(2S), 136-144. 
Semuel, H., Wijaya, S., \& Tendean, A. (2017). Online marketing communication model of the decorative products in Indonesia through user background, cultural experience, website quality, intention and call to action netizen. ACM International Conference Proceeding Series, 446450. https://doi.org/10.1145/3176653.3178 486

Steelyana, E. (2012). Batik, a beautiful cultural heritage that preserve culture and support economic development in Indonesia. Binus Business Review 3(1), 116-130. https://doi. org/10.21512/bbr.v3i1.1288

Thompson, B. (2018). Social media in the built environment. In T. Dixon, J. Connaughton, $\&$ S. Green, Sustainable futures in the built environment to 2050: A foresight approach to construction and development (pp. 223248). USA: Wiley Blackwell.

Turkyilmaz, C. A., Erdem, S., \& Uslu, A. (2015). The effects of personality traits and website quality on online impulse buying. Procedia - Social and Behavioral Sciences, 175, 98-105. https://doi. org /10.1016/j.sbspro.2015.01.1179

Verhagen, T., \& van Dolen, W. (2011). The influence of online beliefs on consumer online impulse buying: A model and empirical application. Information \& Management, 48(8), 320-327. http://dx.doi.org/10.1016/j.im.2011.08.001

Wathen, C. N., \& Burkell, J. (2002). Believe it or not: Factors influencing credibility on the web. Journal of the Association for Information Science and Technology, 53(2), 134-144. https://doi.org/ 10.1002/asi.10016

Wells, J. D., Parboteeah, V., \& Valacich, J. S. (2011). Online impulse buying: Understanding the interplay between consumer impulsiveness and website quality. Journal of the Association for Information Systems, 12(1), 32-56.

Yi, M. Y., Jackson, J. D., Park, J. S., \& Probst, J. C. (2006). Understanding information technology acceptance by individual professionals: Toward an integrative view. Information \& Management, 43(3), 350-363. https://doi.org/10.1016/j.im.200 5.08 .006

Zhang, X., Prybutok, V. R., \& Strutton, D. (2007). Modeling influences on impulse purchasing behaviors during online marketing transactions. Journal of Marketing Theory and Practice, 15(1), 79-89. https://doi.org/10.2753/MTP1069-66791 50106 